\author{
Marta Ronowicz, Piotr Batazy, Maciej CheŁchowski, KajeTAn DeJA, \\ Katarzyna GrZelaK, Monika KęDra, Lech Kotwicki, SŁawomir KWAŚNiewski, \\ JOANNA LEGEŻYŃSKA, ZOFIA SMOŁA, JÓZEF WIKTOR, MARIA WŁODARSKA- \\ KOWALCZUK, PIOTR KUKLIŃSKI
}

Zakład Ekologii Morza

Instytut Oceanologii PAN,

Powstańców Warszawy 55, 81-712 Sopot

E-mail:martar@iopan.pl

\title{
ZASOBY INFORMACJI O RÓŻNORODNOŚCI MORSKICH EUKARYOTA W ZBIORACH NAUKOWYCH INSTYTUTU OCEANOLOGII POLSKIEJ AKADEMII NAUK
}

\section{RYS HISTORYCZNY}

Instytut Oceanologii Polskiej Akademii Nauk (IO PAN) w Sopocie jest stosunkowo młodym ośrodkiem naukowym. Powstał w 1983 r. jako następca działającej od 1953 r. Stacji Morskiej PAN w Sopocie. Od samego początku misja tej stacji było zdobywanie wiedzy o środowisku morskim, głównie w zakresie fizyki, hydrodynamiki, geomorfologii i chemii morza. Do kompletu nauk oceanologicznych brakowało tylko biologii morza i dlatego w 1985 r. powołano pierwsza samodzielną Pracownię Ekosystemów Arktyki pod kierownictwem dr. Jana Marcina Węsławskiego. To właśnie badacze zatrudnieni w tej pracowni zapoczatkowali gromadzenie danych i okazów biologicznych, a zagadnienia dotyczące różnorodności biotycznej obszarów morskich, ze szczególnym uwzględnieniem planktonu i bentosu, od zawsze były w centrum ich zainteresowań naukowych. W 1993 r. Pracownia ta została przekształcona w Zakład Ekologii Morza.

Strategia rozwoju Zakładu, nakreślona i wspierana przez jego kierownika (prof. dr hab. Jana Marcina Węsławskiego, obecnie dyrektora Instytutu), opierała się na eksperckiej znajomości wybranych grup systematycznych organizmów morskich przez jego pracowników. W ten sposób cenne „know-how” zagrożonej „wyginięciem” gałęzi biologii

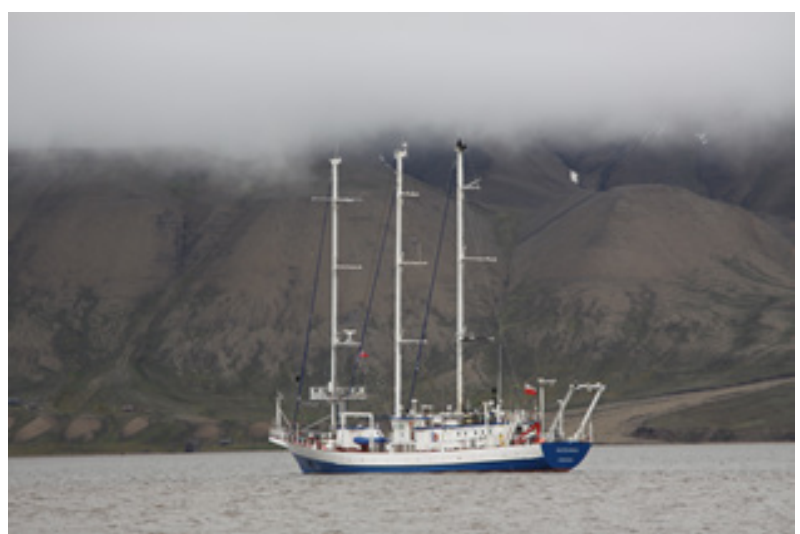

Ryc. 1. Statek badawczy Instytutu Oceanologii PAN s/y Oceania (fot. M. Ronowicz).

jaka jest taksonomia (BOERo 2010) zyskało praktyczne zastosowanie. W kręgu zainteresowań tej grupy badaczy znalazły się: mięczaki (Mollusca), wieloszczety (Polychaeta), skorupiaki (Crustacea), szkarłupnie (Echinodermata), sikwiaki (Sipuncula), nicienie (Nematoda), mszywioły (Bryozoa) i stułbiopławy (Hydrozoa), jak również plankton jednokomórkowy, zooplankton oraz meiofauna, które tworza wielogatunkowe zgrupowania organizmów reprezentujących różne jednostki systematyczne. Zgromadzone dane stały się bazą do badań z zakresu ekologii ewolucyjnej, dynamicznej i populacyjnej.

Słowa kluczowe: bezkręgowce morskie, Instytut Oceanologii Polskiej Akademii Nauk, różnorodność morska, zbiory przyrodnicze

*Artykuł powstał dzięki wsparciu finansowemu z projektu POPC.02.03.01-00-0081/19 „Integracja i mobilizacja danych o różnorodności biotycznej Eukaryota w zasobach polskich instytucji naukowych” (IMBIO). 

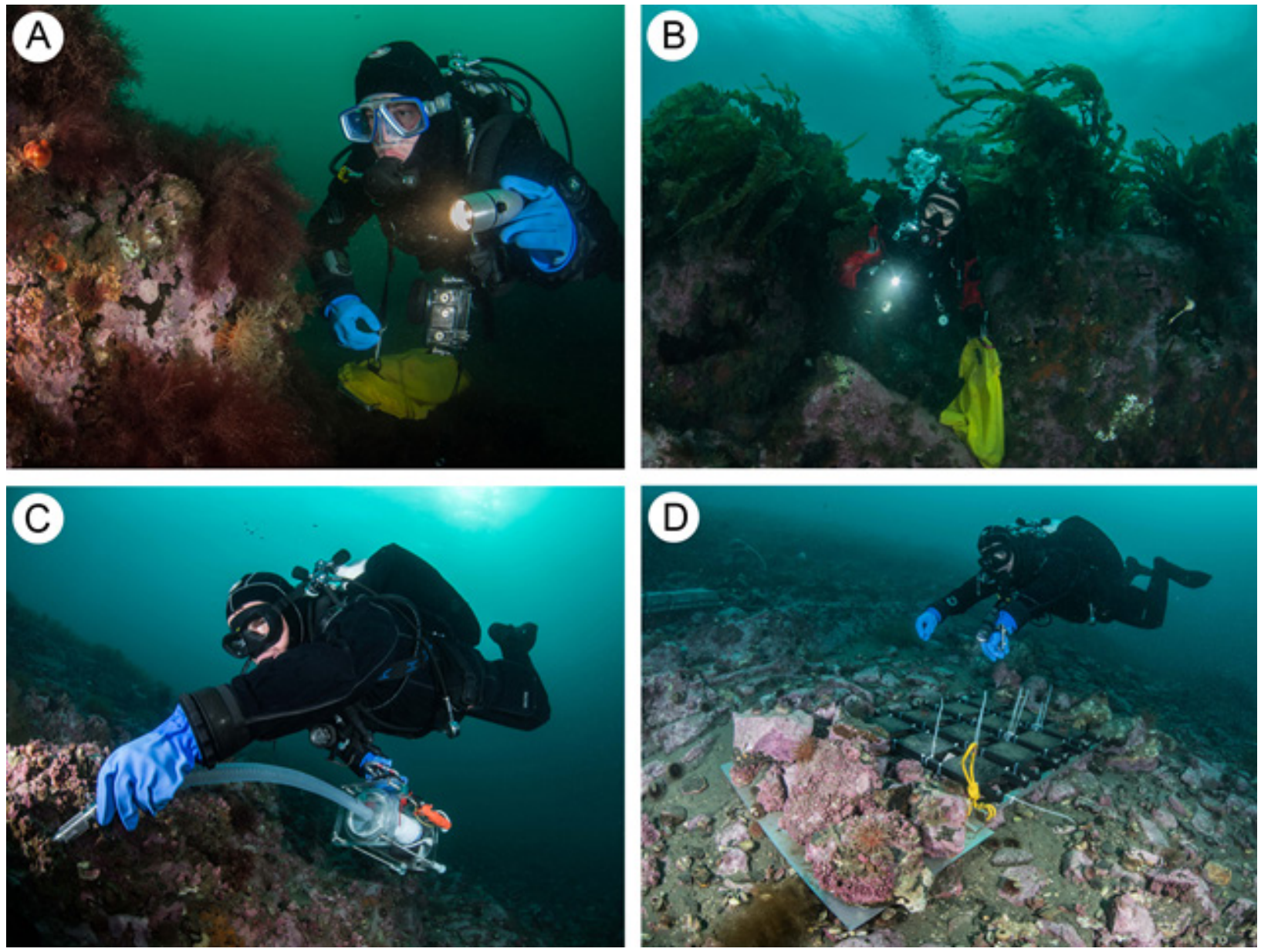

Ryc. 2. Nurkowanie $\mathrm{w}$ badaniach podwodnych $\mathrm{z}$ wykorzystaniem różnych narzędzi; (A) ręczny pobór próbek $z$ dna twardego i (B) z lasu brunatnicowego, (C) manualna pompa ssaca do poboru organizmów z trudno dostępnych zakamarków dna, (D) zestaw paneli eksperymentalnych do badania procesów związanych $z$ kolonizacją dna (fot. P. Kukliński).

Najważniejsza platforma IO PAN do prowadzenia badań na morzu jest statek badawczy s/y Oceania (Ryc. 1), oddany do eksploatacji w 1985 r. Od 1987 r. Oceania corocznie odbywa dwumiesięczne rejsy w rejon obejmujacy obszar od północno-zachodnich wybrzeży półwyspu Skandynawskiego do północnych obrzeży Svalbardu (powyżej $80^{\circ} \mathrm{N}$ ), dostarczajac bogatych zbiorów danych pomiarowych hydrologicznych i kolekcji próbek biologicznych. Obecnie jest to jedyna polska jednostka prowadzaca badania na otwartym oceanie.

Materiały badawcze $z$ morza pozyskuje się z zastosowaniem różnorodnych metod obejmujących nurkowanie w płytkich wodach (Ryc. 2), pobieranie próbek $z$ wykorzystaniem dużych narzędzi połowowych używanych ze statku (takich jak: dragi, czerpacze, rozety, siatki planktonowe oraz batometry i sondy rdzeniowe osadów) (Ryc. 3), a współcześnie również metody zdalne (akustyczne czy optyczne).
Początkowo głównym obszarem badań Zakładu Ekologii Morza były fiordy Svalbardu. Było to zwiazane m.in. $z$ mieqdzynarodowymi programami badawczymi, w których Instytut brał aktywny udział, np. BIODAFF (ang. Biodiversity and Fluxes in Arctic Glaciated Fjords), a następnie BIOMARE (ang. Implementation and networking of large scale, long term MARine BIOdiversity research in Europe) (http://www.biomareweb. org/), którego następca jest MARBEF (ang. Marine Biodiversity and Ecosystem Functioning EU Network of Excellence) (https:// www.marbef.org)). W ramach tych dwóch ostatnich programów wytypowano dwa fiordy (Hornsund i Kongsfjord) zlokalizowane na zachodnim wybrzeżu Spitsbergenu jako europejskie flagowe miejsca badania bioróżnorodności. Dodatkowo Hornsund został wybrany jako obszar All Taxa Biodiversity Inventory, gdzie podjęto się inwentaryzacji całkowitej różnorodności gatunkowej obszarów o wyjatkowych walorach przyrodniczych 

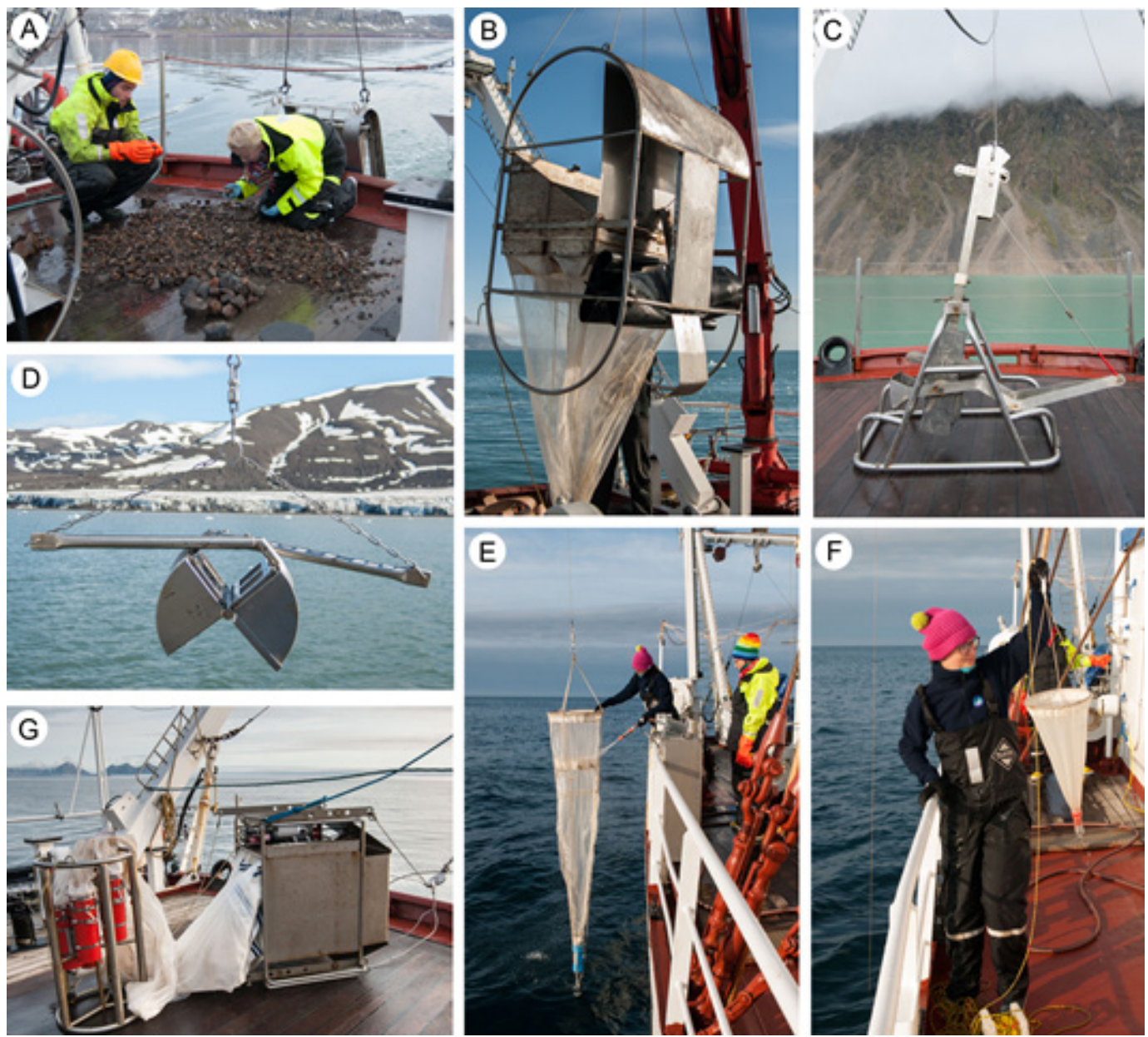

Ryc. 3. Praca na statku i narzędzia połowowe stosowane na s/y Oceania; (A) sortowanie materiału biologicznego $z$ dragi na pokładzie, (B) draga epibentosowa tzw. sanie do łapania organizmów żyjących na dnie, (C) czerpacz skrzynkowy typu box corer służący do poboru rdzeni osadów dennych, (D) czerpacz Van Veen'a stosowany na miękkim dnie, (E) sieć planktonowa typu WP 2 do połowu zooplanktonu, (F) siatka do pobierania próbek fitoplanktonu, (G) sieć typu MultiNet do połowu zooplanktonu $z$ odrębnych warstw wody (fot. P. Kukliński).

i znikomej antropopresji. Obecnie Instytut udostępnia jeden $z$ najbardziej kompletnych katalogów fauny i flory Hornsundu, obejmujący ponad 1200 taksonów (http://www.iopan.gda.pl/projects/ATBI/atbi.html; KĘRA i współaut. 2010).

Z czasem rozszerzono zakres badań o nowe obszary: Morze Beringa, M. Białe, M. Grenlandzkie, M. Norweskie, M. Czukockie i M. Beauforta oraz Archipelag Kanadyjski, a także rejony Antarktyki. Zbiory Instytutu obejmuja także okazy $z$ innych obszarów morskich, oczywiście $z$ Morza Bałtyckiego, ale również $z$ odległych wysp Kanału Mozambickiego, Madagaskaru, Aleutów, Japonii oraz wielu innych lokalizacji.

Zasoby kolekcji organizmów morskich IO PAN szacowane sa na około 77500 okazów. Większość z nich stanowi kolekcja zooplanktonu (ok. 36000 okazów), będacca efektem corocznych rejsów badawczych AREX w re- jon Mórz Nordyckich. Od 1987 r. statek s/y Oceania każdego roku przepływa stała trasa od północnej Norwegii do północno-zachodniego Svalbardu, pobierajac próbki zooplanktonu ze stałych stacji badawczych. Kolekcja ta jest unikatowa w skali światowej i niezwykle cenna ze względu na długotrwały i systematyczny ciag danych $z$ rejonu, znajdującego się pod wpływem zmian klimatycznych spowodowanych globalnym ociepleniem. Pozyskane dane pozwalaja na śledzenie wieloletnich zmian zachodzacych $\mathrm{w}$ składzie zooplanktonu, będącego istotnym komponentem sieci troficznych (WEYDMANN i współaut. 2014, 2018).

Równie ważne sa mniej liczne kolekcje gromadzone przez różnych taksonomów, poczatkowo $\mathrm{w}$ celu katalogowania zidentyfikowanych gatunków, a później także w celach dydaktycznych i szkoleniowych. Sa one również pomocne w weryfikacji niepewnych 

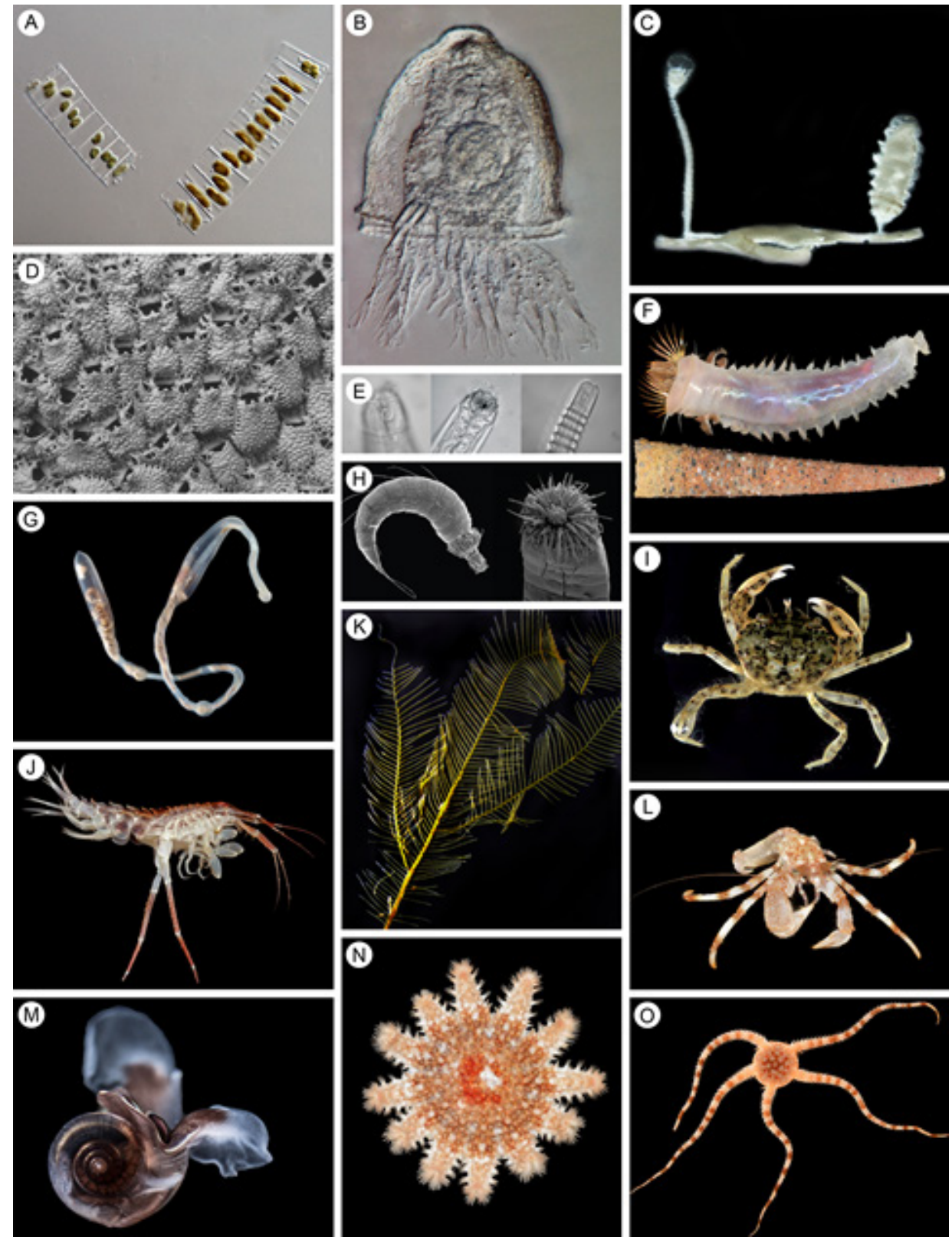

Ryc. 4. Przykłady okazów w kolekcjach IO PAN; (A) przedstawiciele arktycznego mikroplanktonu: $z$ lewej Navicula septentrionalis (Grunow) Gran, 1908 i z prawej Fragilariopsis oceanica (Cleve) Hasle, 1965 - Bacillariophyceae i (B) Ptychocylis obtusa Brandt, 1906 - Ciliophora, (C) Campanularia integra MacGillivray, 1842 - Hydrozoa, (D) Escharoides coccinea (Abildgaard, 1806) - Bryozoa, (E) Nematoda, (F) Pectinaria hyperborea (Malmgren, 1866) - Polychaeta, (G) Nephasoma diaphanes (Gerould, 1913) - Sipuncula, (H) z lewej Echinoderes drogoni Grzelak \& Sørensen, 2018, z prawej Cristaphyes glaurung Sørensen \& Grzelak, 2018 - Kinorhyncha, (I) Rhitropanopeus harrisi (Gould, 1841) - Decapoda, (J) Acanthostepheia malmgreni (Goës, 1866) - Amphipoda, (K) Lytocarpia brevirostris (Busk, 1852) - Hydrozoa, (L) Pagurys prubescens Krøyer, 1838 - Decapoda, (M) Limacina helicina (Phipps, 1774) - Pteropoda, (N) Crossaster papposus (Linnaues, 1767) - Echinodermata, (O) Ophiura sarsii Lütken, 1855 - Echinodermata (fot. J. Wiktor: A, B; M. Ronowicz: C, K; P. Kukliński: D; K. Grzelak: E, H; K. Deja: F, G, J, L-O; P. Bałazy, M. Włodarksa-Kowalczuk: I).

oznaczeń. Szczególne znaczenie historyczne i taksonomiczne w zbiorach Instytutu maja paratypy, czyli okazy $z$ danego stanowiska, z którego okaz typowy (typ) stał się wzorem do opisu nowego gatunku dla nauki.
W ramach projektu IMBIO (Integracja i mobilizacja danych o różnorodności biotycznej Eukaryota w zasobach polskich instytucji naukowych) posiadane kolekcje okazów zostana usystematyzowane i uporządkowane, 
a dane o zasobach zostana zorganizowane w postaci cyfrowej, w formie baz metadanych. Informacje o poszczególnych osobnikach, jakie znalazły się na etykietach zbioru, udostępnione poprzez Krajowa Sieć Informacji o Bioróżnorodności (KSIB) i Globalna Usługę Informacji o Bioróżnorodności (GBIF) umożliwia łatwiejsze korzystanie ze zgromadzonych zbiorów przyrodniczych szerszemu gronu odbiorców. Przykłady morskich okazów Eukaryota $z$ różnych kolekcji zgromadzonych w IO PAN przedstawiono na Ryc. 4.

\section{KOLEKCJE W ZASOBACH IO PAN}

Poniżej przedstawiono opisy wszystkich kolekcji morskich znajdujących się obecnie w zasobach Instytutu Oceanologii Polskiej Akademii Nauk. Najpierw, według nazewnictwa naukowego, podano alfabetycznie nazwy poszczególnych taksonów, których okazy znajduja się w zbiorach, a potem według kolekcji reprezentujacych różne zgrupowania, z osobnymi ujęciami Kinorhyncha (ryjkogłowy) i Nematoda (nicienie).

\section{BRYOZOA (MSZYWIOŁY)}

Sa to osiadłe kolonijne organizmy filtrujace. Typ ten obejmuje około 6000 opisanych dotychczas gatunków. Zasiedlaja całe dno przeważnie środowisk morskich, ale także słodkowodnych, od strefy pływów do najgłębszych abysalnych rejonów wszechoceanu. Występuja we wszystkich rejonach klimatycznych od tropików po rejony polarne. Kolonie mszywiołów tworza często tysiace osobników, rzadko przekraczających $1 \mathrm{~mm}$ wielkości, o różnorodnych formach morfologicznych, od prostych płaskich, poroślowych do skomplikowanych, trójwymiarowych konstrukcji, przypominajacych drzewka bacdź krzaczki. Takie kolonie moga osiagać często ponad $20 \mathrm{~cm}$ wysokości. Mszywioły sa organizmami pionierskimi kolonizujacymi nowo odsłonięte połacie dna morskiego. Ich kolonie stanowia także schronienie dla innych organizmów, tworząc unikatowe nisze siedliskowe. Duże lokalne zagęszczenie zgrupowań takich kolonii prowadzi do transferu energii do wyższych poziomów troficznych, a po obumarciu ich węglanowe szkielety przyczyniaja się do tworzenia nowych osadów i skał.

Kolekcja mszywiołów jest bardzo zróżnicowana pod względem pochodzenia geograficznego. Obejmuje okazy z: Arktyki (około 200 gatunków), Antarktyki ( 120 gatunków), Północnego Atlantyku ( 50 gatunków) i Pacyfiku ( 50 gatunków). Gromadzenie Bryozoa w Instytucie zostało zainicjowane w 1997 r. wraz $z$ rozpoczecciem zintensyfikowanych badań tego taksonu.
Najbogatszą kolekcję stanowia mszywioły pochodzace $z$ Arktyki. Długa tradycja badań prowadzonych przez IO PAN w obrębie Archipelagu Svalbard, $z$ jego największa wyspa Spitsbergen, pozwoliła na zgromadzenie tych unikatowych zbiorów. Obejmuja one zarówno materiały pobierane ze statków $\mathrm{s} / \mathrm{y}$ Oceania i r/v Jan Mayen, jak również bezpośrednio przez nurka. Do poboru próbek $z$ większych głębokości stosowano czerpacze i dragi, a $z$ rejonów płytszych $\quad(<30$ m) materiały często były pobierane ręcznie. Kolekcja ta obejmuje zgrupowania $Z$ szerokiego zakresu głębokości, począwszy od strefy pływów do 400 metrów głębokości. Mszywioły żyja na różnych stałych podłożach: na muszlach mięczaków (żywych i martwych), innych koloniach Bryozoa, plechach glonów, a także na strukturach nieorganicznych, np. skały, burty statków, itp. Często każde $z$ tych podłoży zasiedlaja odmienne zgrupowania mszywiołów. Wszystkie podłoża wraz ze zgrupowaniami Bryozoa sa przechowywane w zbiorach $\mathrm{w}$ postaci zasuszonej lub zakonserwowanej w roztworze formaldehydu i alkoholu. Węlanowa pochewka (zooecjum) pojedynczego osobnika (zooid) kolonii Bryozoa stanowi podstawową cechę diagnostyczną w ustalaniu rangi systematycznej danego taksonu. Wysuszone mszywioły moga być więc przechowywane przez lata, nie tracac widocznych cech morfologicznych potrzebnych w taksonomii.

Instytut posiada również kolekcje Bryozoa z Belgica Bank, obszaru położonego u wschodnich wybrzeży Grenlandii, które zostały podarowane przez dr Beate Badder. Próbki te zostały zebrane za pomoca trału Agassiz $z$ kilku stacji badawczych, $z$ głębokości od 75 do $211 \mathrm{~m}$ podczas rejsu statku r/v Polarstern. Natomiast kolekcja mszywiołów z Morza Łaptiewów została podarowana przez Instytut Ekologii Polarnej z Kilonii (Niemcy). Co prawda, jest to zbiór niewielki, jednak dość unikatowy, pochodzący $z$ trudno dostępnego rejonu Arktyki rosyjskiej. W instytutowych zasobach mszywiołów arktycznych jest też kolekcja $z$ rejonów Morza Czukockiego i Morza Beauforta, podarowana przez Uniwersytet Fairbanks (USA) oraz z Arktyki Kanadyjskiej, podarowana przez Uniwersytet Rimouski (Kanada). Obie te kolekcje mają również unikatowy charakter, gdyż pochodza $z$ rejonów ciagle jeszcze trudno dostępnych $i$ nie w pełni zbadanych.

W 2011 r. Instytut uczestniczył w badaniach naukowych Wysp Aleuckich (Pó1nocny Pacyfik). Ich efektem było nagromadzenie materiału biologicznego $z$ płytkowodnych rejonów (do $20 \mathrm{~m}$ głębokości) wysp 
Adak i Amchitka, metoda nurkowania podczas rejsu statku r/v Norseman.

W latach 2005-2014 zebrano wiele okazów wraz $z$ kamiennymi podłożami kolonii mszywiołów z Północnego Atlantyku, włączając w to Szetlandy i kilka lokalizacji od Bergen do Tromsø (Norwegia). Kolekcja ta reprezentuje faunę poroślowa, której mszywioły sa grupa najliczniejsza pod względem bogactwa gatunkowego. Materiały te zostały zebrane metoda nurkowania głównie $z$ głębokości do $12 \mathrm{~m}$. Jednak większa część tej kolekcji pochodzi $z$ Trondheimfjorden. Obejmuje ona zarówno organizmy płytkowodne, jak również okazy z większych głębokości (do 200 metrów).

Antarktyka jest kolejnym rejonem pochodzenia kolekcji mszywiołów IO PAN. Najwięcej okazów antarktycznych gatunków zostało zebranych w Zatoce Admiralicji (Wyspa Króla Jerzego), gdzie znajduje się Polska Stacja Antarktyczna im. Henryka Arctowskiego. Zostały one pozyskane $z$ głębszych (od 91 do $145 \mathrm{~m}$ ) rejonów zatoki za pomoca czerpacza przez naukowców z Uniwersytetu Łódzkiego podczas rejsu rosyjskiego statku Polar Pioneer w trakcie Międzynarodowego Roku Polarnego

w 2007 r. i przekazane Instytutowi. Kolekcje te sa zakonserwowane w alkoholu. Na przełomie lat 2010 i 2011 pozyskano również próbki (fragmenty podłoży skalistych, ze znacznym udziałem Bryozoa) metoda nurkowania $z$ płytszych $(6-30 \quad \mathrm{~m})$ części Zatoki Admiralicji. Sa one przechowywane $\mathrm{w}$ formie wysuszonej.

W zasobach Instytutu jest też wiele pojedynczych osobników mszywiołów pochodzacych $z$ Grenlandii i Islandii, które zostały przekazane przez Zoologiczne Muzeum w Kopenhadze oraz Muzeum Historii Naturalnej w Sztokholmie. Sa wśród nich unikatowe ze względów historycznych okazy, które oznaczyli Karen Billy Hansen i George Marius Levinsen, sławni duńscy taksonomowie ubiegłych wieków. Sa też okazy mszywiołów zebrane podczas słynnej szwedzkiej ekspedycji statkiem Vega, który uczestniczył w historycznym rejsie przepłynięcia Przejścia Północno-Wschodniego wzdłuż wybrzeża Rosji w latach 1878-1879.

$\mathrm{Na}$ bazie tych kolekcji opisano nowe dla wiedzy: 2 rodzaje i 19 mszywiołów, głównie $z$ Arktyki i Antarktyki (KUKLIŃSKI i współaut. 2005, KUKLIŃSKI i BADER 2007, KUKLIŃSKI 2013, KRZEMINSKA i współaut. 2018) oraz powstało wiele doktoratów i innych publikacji naukowych.

Ponieważ IO PAN nie jest typowo muzealna jednostka, dlatego wszystkie okazy typowe zostały przekazane do Muzeum Historii Naturalnej w Londynie.

\section{CRUSTACEA (SKORUPIAKI)}

Crustacea (skorupiaki) sa obecnie podtypem stawonogów (Arthropoda) i obejmuja blisko 70000 opisanych gatunków na świecie. Sa to głównie zwierzęta wodne, szczególnie różnorodne $\mathrm{w}$ oceanach, gdzie zasiedlaja wszelkie możliwe siedliska, łacznie $z$ lodem morskim i najgłębszymi strefami oceanicznymi. Rozmiary tych bezkręgowców wahają się od $0,1 \mathrm{~mm} u$ form planktonowych do kilkudziesięciu centymetrów u krabów (Brachyura) i homarów (Nephropidae) oraz głębinowych równonogów (Isopoda) i obunogów (Amphipoda). Dla przykładu, Macrocheira kaempferi Temminck, 1836, japoński krab pacyficzny lub krab olbrzymi ma karapaks o średnicy $40 \mathrm{~cm}$, a rozpiętość jego odnóży dochodzi do $4 \mathrm{~m}$. Gatunek ten jest największym spośród żyjących współcześnie stawonogów. Skorupiaki charakteryzują się olbrzymia różnorodnościa morfologiczna oraz ekologiczna i odgrywaja znaczaca rolę w ekosystemach wodnych, a także jako cenne źródło pokarmu człowieka, np. wspomniane kraby, homary i krewetki (Caridea).

Kolekcja skorupiaków IO PAN liczy 504 okazy należące do 202 gatunków, które zostały zebrane w latach 1997-2019 w Północnym Atlantyku, Arktyce i Oceanie Południowym, $z$ zastosowaniem różnorakich metod: czerpacze, dragi, siatki ręczne, pułapki z przynęta, nurkowanie. Dzięki temu obejmuje ona gatunki reprezentujace różnorodne strefy mórz, począwszy od strefy pływów aż do abysalu. Większość okazów należy do gromady pancerzowców (Malacostraca). Reprezentują one zarówno formy denne, jak również pelagiczne, różniąc się wielkościa, mobilnościa i sposobem odżywiania. W zbiorach znajduje się paratyp (okaz gatunku nowo opisanego dla wiedzy) Rhachotropis northriana d'Udekem d'Acoz, Vader \& Legeżyńska, 2007 obunoga $z$ rodziny Eusiridae (holotyp przechowywany jest w Muzeum Uniwersyteckim w Tromsø), a także okaz obunoga Guernea (Prinassus) nordenskioldi (Hansen, 1888), gatunku nowego dla fauny archipelagu Svalbard (D'UDEKEM D'ACOZ i współaut. 2007, LEGEŻYŃSKA i współaut. 2015). Wszystkie okazy zakonserwowane sa $70 \%$ etanolem.

Wśród liczniejszych bardzo interesujacych okazów opisywanej kolekcji skorupiaków sa przedstawiciele rodziny Paguridae, zwanej po polsku pustelnikowate lub kraby pustelniki, która reprezentuje rząd Decapoda (dziesięcionogi). Do osłony swego miękkiego odwłoka używają głównie pustych muszli ślimaków. Te twarde, mobilne podłoża sa często bardzo dogodnym środowiskiem do życia dla wielu innych organizmów osiadłych, tzw. epifauny. Jednym $z$ najlepiej poznanych przedstawi- 
cieli tej grupy jest Pagurus bernhardus (Linnaeus, 1795), pustelnik bernardyn pochodzacy ze Szkocji, z którym stowarzyszonych jest prawie 120 innych gatunków (WILLIAMS i MCDERMOT 2004). Nic więc dziwnego, że skorupiaki te sa wykorzystywane często jako dogodny model do badań nad testowaniem różnego rodzaju hipotez dotyczacych różnorodności.

Zbiór krabów pustelników pochodzi $z$ europejskiej części Arktyki, $z$ rejonu Północnej Norwegii (Mjosund, okolice Troms $\varnothing$ ) oraz fiordów zachodniego Spitsbergenu (głównie Isfjordu: okolice Fuglefjella i dawnej osady Grumantbyen). Kolekcja ta obecnie liczy ponad 400 okazów należacych do 2 gatunków: Pagurus bernhardus - występujacy w wodach Norwegii oraz P. pubescens Krøyer, 1838 - Z pobrzeży Norwegii i Spitsbergenu. Archipelag Svalbard położony jest na północnej granicy występowania obydwu gatunków. Pustelniki zbierane były głównie na potrzeby projektu opisującego czynniki kontrolujące bioróżnorodność na twardym, mobilnym podłożu biotycznym. Oznacza to, że do większości okazów jesteśmy w stanie dopasować odpowiadajacca im charakterystykę muszli danego ślimaka, która stanowiła ochronę skorupiaka. W tym przypadku dodatkowe informacje obejmują: gatunek ślimaka, masę muszli, ewentualne jej uszkodzenia, szacowana powierzchnię oraz gatunki i liczebność epibiontów na niej osiadłych. W rejonie Spitsbergenu zarejestrowano ponad 80 gatunków epibiontów, wśród których wyraźnie dominują pakkle $z$ gatunku Semibalanus balanoides (Linnaeus, 1767), wieloszczety (Polychaeta) osiadłe $z$ rodziny Serpulidae: Circeis armoricana (Saint-Joseph, 1894), Spirorbis sp./Bushiella sp./Pilleolaria sp., Paradexiospira sp. i mszywioł Celleporella hyalina (Linnaeus, 1767). W wodach Norwegii stwierdzono tylko 50 gatunków, prawdopodobnie $z$ powodu mniejszej liczby próbek. Wśród nich dominowały dwa gatunki otwornic (Foraminifera) reprezentujacych królestwo protistów (Protista): Discorbis rosacea (d'Orbigny, 1826) i Lobatula lobatula (Walker \& Jacob, 1798), wieloszczety $z$ gatunku Spirobranchus triqueter (Linnaeus, 1758) oraz małże Hiatella arctica (Linnaeus, 1767).

Zgromadzone w latach 2006-2009 zbiory $z$ Norwegii i ze Spitsbergenu moga zostać wykorzystane do śledzenia wpływu wieloletnich zmian środowiskowych na populacje pustelników, będących ważną częścią arktycznych ekosystemów, zarówno ze względu na znaczna liczebność (BAtAzY i współaut. 2015) oraz $z$ tego powodu, że skorupiaki te maja widoczny udział w inżynierii struktury tego środowiska (BAŁAZY i KUKLIŃSKI 2013). Wykazano, że epifauna muszli krabów pu- stelników reaguje istotnie na czynniki środowiskowe zwiazane $z$ tzw. oscylacja północnoatlantycka (NAO) i wartości tego wskaźnika, zwłaszcza zima (BAŁAZY i KUKLIŃSKI 2019). Okazy te, zakonserwowane roztworem formaldehydu, poławiali nurkowie w płytkiej (15-20 m głębokości) części sublitoralu.

\section{ECHINODERMATA (SZKAREUPNIE)}

Echinodermata (szkarłupnie) sa typem halobiontycznych (żyją wyłącznie w środowisku morskim) bezkręgowych zwierzat wtóroustych (Deuterostomia) o wtórnej symetrii pięciopromiennej i obejmuja ponad 7000 gatunków żyjacych współcześnie na Ziemi. $Z$ uwagi na rozmiar zaliczane sa do tzw. megabentosu, czyli organizmów większych niż $2 \mathrm{~cm}$. Zasiedlają dno twarde i miękkie, zarówno płytkich, jak i głębokich stref oceanicznych. Większość gatunków należy do epifauny lub inaczej epibentosu (stale przebywaja w pobliżu dna), ale wiele gatunków reprezentuje także infaunę (zagrzebujących się w dnie). Szkarłupnie reprezentują zarówno gatunki drapieżne, detrytusożerne, filtrujace jak też roślinożerne. Przedstawiciele gromady Ophiuroidea (wężowidła) $z$ rejonów polarnych występuja często bardzo licznie w akwenach przylodowcowych, do których inne organizmy się nie przystosowały. Pomimo pozornie małej mobilności (choć wężowidła sa najbardziej ruchliwymi i szybko przemieszczającymi się szkarłupniami), drapieżne gatunki, takie jak np. Ophiura sarsii Lütken, 1855, potrafią złapać swoimi silnie umięśnionymi ramionami przepływające nad dnem małe organizmy.

Kolekcja szkarłupni arktycznych liczy 150 osobników należących do 10 gatunków zebranych w rejonie Svalbardu, głównie w zachodnich fiordach Spitsbergenu, ale te $\dot{z} \mathrm{w}$ trudno dostępnej Cieśnienie Hinlopen oraz głębokich wodach Cieśniny Fram. Większość $z$ nich została pozyskana za pomoca narzędzi wleczonych po dnie za statkiem, takich jak sanie epibentosowe, czy draga trójkatna. Niektóre okazy zostały złowione także przez nurków lub za pomoca czerpacza Van Veena, czy też czerpacza skrzynkowego. Niektóre $z$ nich zostały zasuszone, a inne sa zakonserwowane w roztworze formaldehydu. Kolekcja tych szkarłupni obejmuje głównie okazy reprezentujace wężowidła, 3 gatunki należą do gromady Asteroidea (rozgwiazdy), a 1 do Echinoidea (jeżowce).

Interesujaca jest też kolekcja szkarłupni antarktycznych $z$ Wyspy Króla Jerzego w fiordzie Ezcurra, który jest częścią Zatoki Admiralicji. Bezkregowce te zostały zebrane $z \quad 8$ stacji badawczych, $z$ głębokości od 6 do $30 \mathrm{~m}$, w trakcie nurkowania. Kolekcja ta liczy 600 osobników reprezentujących 23 
taksony, z których najwięcej należy do rozgwiazd, grupy o względnie największym bogactwie gatunkowym oraz jeżowców - najbardziej liczebnych $\mathrm{w}$ osobniki. W kolekcji tej sa również obecne gatunki reprezentujace inne gromady: wężowidła, strzykwy (Holothuroidea) i liliowce (Crinoidea). Większość $z$ nich po złowieniu została zakonserwowana w roztworze formaldehydu, a niewielka część próbek jeżowców w alkoholu.

\section{HYDROZOA (STUŁBIOPŁAWY)}

Hydrozoa (stułbiopławy) sa gromada typu parzydełkowców (Cnidaria) obejmująca ponad 3700 gatunków, głównie morskich, charakteryzujacych się w swoim rozwoju występowaniem dwóch postaci, polipa i meduzy lub jednej nich. Ta kolekcja obejmuje wyłącznie okazy hydropolipów, które w przeważającej większości tworza osiadłe drzewkowate formy kolonijne lub kolonie płożące się po podłożu. Najczęściej można je spotkać na takich podłożach jak makroglony, dno twarde, lub na powierzchni innych organizmów, np. na muszlach mięczaków lub na mszywiołach czy paklach oraz innych parzydełkowcach. Często tworza trójwymiarowe struktury stanowiące podłoże dla innych organizmów lub miejsce składania jaj. Należa przeważnie do filtratorów wyłapujących $\mathrm{z}$ toni wodnej drobne organizmy, stanowiąc znaczace ogniwo w przepływie energii i obiegu materii $z$ pelagialu i litoralu do bentosu.

Kolekcja stułbiopławów liczy ponad 500 okazów reprezentujących 103 gatunki, z których większość pochodzi $z$ rejonu Svalbardu, ale sa również osobniki $z$ Oceanu Indyjskiego (Komory, Reunion, Madagaskar, Japonia), Morza Bałtyckiego, Morza Białego i Kanału La Manche. Były one zebrane w różny sposób: bezpośrednio przez nurkowanie swobodne lub za pomoca dragi i czerpaczy dennych. Najlepiej zachowane sa okazy, które zostały zebrane przez nurków. Ze względu na bardzo delikatne struktury, kolonie hydropolipów łatwo ulegaja uszkodzeniom mechanicznym, stąd nurkowanie jest najlepszą i najbardziej skuteczna metoda pozyskiwania tych organizmów $\mathrm{w}$ rejonach płytkiego dna twardego. Materiał został zebrany od strefy pływowej do głębokości $5561 \mathrm{~m}$ (Cieśnina Fram). Hydropolipy pozyskano także z płytek kolonizacyjnych umieszczanych na dnie podczas eksperymentów prowadzonych na niewielkich głębokościach $(5-10 \mathrm{~m}) \mathrm{w}$ Isfjordzie i na dużych głębokościach (do 5561 m) w Cieśninie Fram. Okazy w większości zostały zakonserwowane w $70 \%$ etanolu, a niektóre w 4\% roztworze formaldehydu.

Kolekcja stułbiopławów zawiera trzy okazy paratypowe; jeden gatunek pochodzi ze zbiorowiska podwodnego lasu brunatnicowe- go na Spitsbergenie (RONOwICZ i SCHUCHERT 2007), a dwa inne gatunki $z$ rejonu Kanału Mozambickiego (RoNOWICZ i współaut. 2017). Okazy holotypowe trafily do Muzeum Historii Naturalnej w Genewie i do Muzeum Historii Naturalnej w Paryżu.

Szczególnie cennym okazem jest Halisiphonia arctica Kramp, 1932, który znany był bardzo długo jedynie $z$ opisu holotypu. Dopiero w 2011 r., po prawie 80. latach od opisania, gatunek ten został ponownie zaobserwowany na eksperymentalnych panelach umieszczonych na głębokości $2500 \mathrm{~m}$ w rejonie Hausgarten (Cieśnina Fram).

\section{MOLLUSCA (MIECZAKI)}

Mollusca (mięczaki) sa po stawonogach najbardziej różnorodnym na świecie typem obejmującym około $150 \quad 000$ gatunków. Charakteryzuja się olbrzymia różnorodnościa morfologiczną i zróżnicowanymi rozmiarami. Żyja zarówno na lądzie, jak i w wodach, a w środowisku morskim należą do najbogatszej i najbardziej zróżnicowanej grupy organizmów obejmującej około $23 \%$ wszystkich znanych dotychczas gatunków morskich.

Często dominuja w zgrupowaniach makrofauny Arktyki, zarówno pod względem liczebności, biomasy, jak również bogactwa gatunkowego. Kolekcja Mollusca IO PAN obejmuje osobniki zbierane w wodach przybrzeżnych archipelagu Svalbard, Grenlandii i Norwegii w latach 1996-2020, w szerokim zakresie głębokości (0-2000 m, od strefy pływowej po stok kontynentalny). Sa one konserwowane w 4\% roztworze formaldehy$\mathrm{du}, \mathrm{a}$ następnie przechowywane $\mathrm{w}$ alkoholu etylowym lub wysuszone. Fiord Kongsfjorden jest jednym $z$ najintensywniej przebadanych obszarów morskich. W siedliskach jego dna miękkiego (dno muliste, piaszczyste, mieszane) i twardego (półki skalne, lasy brunatnic) zebrano za pomocy narzędzi przeznaczonych do połowu infauny (czerpacz Van Veena i skrzynkowy) oraz epifauny (draga epibentosowa, pułapki nekrofagiczne, pobór przez nurka) ponad 35 tysięcy osobników należących łącznie do 87 gatunków, które reprezentuja: Bivalvia (małże), Gastropoda (ślimaki), Polyplacophora (chitony) i Caudofoveata (tarczonogie) (WŁODARSKA-KOWALCZUK 2007).

\section{POLYCHAETA (WIELOSZCZETY)}

Polychaeta (wieloszczety) sa bardzo stara filogenetycznie i silnie zróżnicowana pod względem taksonomicznym gromadą obejmująca około 15000 gatunków należących do typu pierścienice (Annelida). Jest to grupa bardzo zróżnicowana morfologicznie i ekologicznie.

Wieloszczety występują przede wszystkim w morzach, gdzie są bardzo powszechne. 
Zasiedlają wszystkie środowiska morskie od wybrzeży po największe głębiny oceaniczne, we wszystkich strefach klimatycznych. Żyja jako formy wolne lub osiadłe, głównie w strefie przybrzeżnej, w piasku lub mule dna morskiego, ale znane sa także formy pelagiczne. Pełnia wiele ważnych funkcji w ekosystemie, m.in. w obiegu biogenów. Wieloszczety często dominuja wśród zgrupowań organizmów bentosowych (dennych). Kolekcja Polychaeta liczy 700 okazów należacych do około 150 gatunków. Zostały one zebrane w Arktyce, w większości w rejonie Svalbardu, ale również w Morzu Barentsa i Morzu Czukockim, a także w rejonach głębokiego Oceanu Arktycznego (m.in. KE ERA i współaut. 2013, OleszczUK i współaut. 2021). Próbki osadu, $z$ których pozyskano wieloszczety, pobierane były przede wszystkim za pomoca czerpaczy (Van Veen oraz skrzynkowe, typu box corer), od płytkich rejonów szelfowych aż do głębokości ponad $2000 \mathrm{~m}$, głównie $z$ dna mulistego. Okazy były konserwowane formalina, a następnie przeniesione do 70\% etanolu, a nieliczne do 50\% propanolu.

\section{SIPUNCULA (SIKWIAKI)}

Sipuncula (sikwiaki) są grupa wyłącznie morskich bezkręgowców pierwoustych (Protostomia) w randze typu, obejmujaca około 150 opisanych gatunków na świecie. Występuja w różnych strefach klimatycznych, od tropików po wody polarne, na różnych głębokościach, w większości jednak w wodach płytkich, Niektóre gatunki zagrzebuja się w piasku lub mule dennym, inne zasiedlaja szczeliny skalne lub opuszczone muszle małży, ślimaków czy domki wieloszczetów. Pomimo ubóstwa gatunkowego wiele sikwiaków często pełni ważne funkcje w ekosystemach morskich, sa np. ważnym źródłem pożywienia dla ryb, i morsów, a w niektórych rejonach populacje pewnych gatunków sa bardzo liczne i dominuja w biomasie zgrupowań bentosowych. Sikwiaki sa często pomijane w badaniach ekologicznych, gdyż prawidłowe oznaczenie do rangi gatunków wymaga specjalistycznej wiedzy taksonomicznej i przeprowadzenia sekcji zwierzęcia. W zbiorach Instytutu jest 200 okazów należacych do 11 gatunków pozyskanych $Z$ obszaru Arktyki, w większości z rejonu Svalbardu, ale również z Morza Barentsa i pacyficznej części Arktyki (Morza Beringa, Morza Czukockiego, Morza Beauforta), a także z głębokich rejonów Oceanu Arktycznego (KEDRA i WŁODARSKA-KOWALCZUK 2008, KĘDRA i SHIELDS 2011, KĘDRA i współaut. 2018). Pochodzace $z$ płytkich rejonów szelfowych (do głębokości ponad $2000 \mathrm{~m}$ ), zarówno $\mathrm{z}$ dna mulistego, jak i $z$ osadów $z$ duża ilościa żwiru i kamieni, próbki osadu $\mathrm{z}$ sikwiaka- mi pobierano przede wszystkim za pomoca czerpaczy (Van Veen oraz skrzynkowe, typu box corer). Większość okazów sipuncula była konserwowana formaliną, a następnie przeniesiona do $70 \%$ etanolu, a nieliczne do $50 \%$ propanolu.

\section{MEIOFAUNA}

Meiofauna jest niezwykle różnorodnym i bogatym w gatunki zespołem organizmów środowisk wodnych, od regionów polarnych po tropikalne, reprezentowanym przez praktycznie wszystkie grupy bezkręgowców, które osiagaja rozmiary do kilku milimetrów. Chociaż organizmy tworzace meiofaunę mogą odgrywać ważna rolę w funkcjonowaniu ekosystemów morskich, jej bogactwo gatunkowe jest trudne do dokładnego oszacowania. Powodem tego sa trudności w pracy $z$ mikroskopijnymi organizmami, niewielka liczba specjalistów i czasochłonność analiz próbek, co często wymusza identyfikację organizmów meiofauny jedynie do poziomu wyższych kategorii taksonomicznych. Stąd wiedza, nie tylko na poziomie gatunkowym, ale także wyższej rangi taksonów jest względnie skappa. Szczegółowe analizy taksonomiczne przyczyniaja się do wypełnienia luki w kluczowych kwestiach dotyczących różnorodności, rozmieszczenia i ekologii zgrupowań bentosowych $z$ wielu regionów i stref klimatycznych. Dlatego zajmowanie się nia jest nie lada wyzwaniem. Skatalogowane kolekcje organizmów $z$ próbek meiofauny obejmuja jedynie jednostki taksonomiczne (gromady, rzędy, czasami rodziny) wyższej rangi. Materiały te zostały zebrane $z$ piaszczystych plaż Arktyki, rejonów umiarkowanych Morza Bałtyckiego i Morza Północnego oraz stref subtropikalnych i tropikalnych, aż po plaże antarktyczne (KOTWICKI i współaut. 2005). W kolekcji opisano ponad 2000 okazów meiofauny plażowej. Materiał standardowo pobierany był przy użyciu rdzenia o powierzchni chwytnej $10 \mathrm{~cm}^{2}$. Metoda ta była stosowana we wszystkich badaniach, niezależnie od czasu i miejsca (KOTWICKI i współaut. 2005, 2014a, b; KOTWICKI i SzCZUCIŃSKI 2006). W przypadku części materiału, rdzenie osadu $z$ meiofauna zostały dodatkowo podzielone wertykalnie, pozwalając tym samym na określenie składu taksonomicznego i rozmieszczenia organizmów w poszczególnych warstwach osadu. Zebrane i skatalogowane próbki zawierajace okazy wybranych wyższych taksonów moga służyć w przyszłości do dalszej i dokładniejszej analizy taksonomicznej. Wśród zbiorów $z$ meiofauna wyodrębniono kolekcje ryjkogłowych i nicieni.

\section{Kinorhyncha (ryjkogłowe)}

Kinorhyncha (ryjkogłowe) sa typem miniaturowych $(0,2-1 \mathrm{~mm})$, wyłącznie mor- 
skich, drapieżnych bezkręgowców, do którego zalicza się około 300 gatunków, z czego tylko 25 znanych $z$ rejonu Arktyki. Zasiedlaja praktycznie każde środowisko bentosu oceanicznego na wszelkich głębokościach i we wszystkich oceanach swiata, od strefy płytkowodnej po głęboki ocean, od gruboziarnistych osadów piaszczystych po osady mułowe. Żywią się tym, co znajda w osadzie, np. okrzemkami. Sa bardzo słabo poznana grupa bezkręgowców.

W zasobach IO PAN kolekcja ryjkogłowych liczy ponad 1000 osobników reprezentujących 8 gatunków, należących do rodzaju Echinoderes. W kolekcji znajduje się 5 gatunków które opisano z rejonu Grenlandii w latach 80. XX w., a których obecność stwierdzono także w rejonie Spitsbergenu oraz 3 nowo opisane dla wiedzy gatunki ze spitsbergeńskich fiordów (GRZELAK i SøRENSEN 2018). Sa one utrwalone i przechowywane $\mathrm{w}$ postaci preparatów mikroskopowych. Wszystkie okazy pochodza z europejskiego sektora Arktyki, w większości z zachodnich fiordów Spitsbergenu, ale również $z$ arktycznych basenów zlokalizowanych na północ od Spitsbergenu, a także Morza Barentsa oraz Storfjordu. Próbki Kinoryncha zbierane były przy pomocy sondy rdzeniowej, wykorzystywanej do próbkowania osadów mulistych w stosunkowo szerokim gradiencie batymetrycznym: od 60 do 2200 $\mathrm{m}$. Kolekcja ta obejmuje okazy paratypowe. Okazy holotypowe zostały zdeponowane w kolekcji Muzeum Historii Naturalnej w Kopenhadze, razem $z$ holotypami 6 innych nowych dla nauki gatunków Kinorhyncha opisanych $z$ rejonu Spitsbergenu (SøRENSEN i GRZELAK 2018, GRZELAK i SøRENSEN 2019). Nazwy wszystkich nowych dla nauki gatunków nawiazuja do imion smoków $z$ powieści Georga R.R. Martina i Johna R.R. Tolkiena.

\section{Nematoda (nicienie)}

Nematoda (nicienie) sa dominuja grupa organizmów w meiofaunie. Ze względu na szereg morfologicznych i metabolicznych przystosowań $z$ wielkim sukcesem kolonizuja nawet ekstremalne środowiska. Pod względem liczebności i biomasy, nicienie moga stanowić nawet 90-95\% całej meiofauny. Dotychczas opisano około 7000 morskich gatunków Nematoda na świecie, ale szacunki wskazują, że może ich być nawet 50000 (APPELTANS i współaut. 2012). Bogata kolekcja preparatów stałych zawiera okazy reprezentujace ponad 200 rodzajów wolnożyjacych morskich Nematoda, pochodzacych z różnych rejonów świata i szerokiego gradientu batymetrycznego, od strefy brzegowej po strefe głębokowodna $(0-5500 \mathrm{~m})$. Większość próbek została zebrana w rejonie Arktyki
Europejskiej (Cieśnina Fram, Spitsbergen, Yermak Plateau, Morze Barentsa), ale w kolekcji znaleźć można także próbki $z$ głębokowodnych basenów Morza Bałtyckiego (Głębia Gotlandzka, Głębia Bornholmska, Głębia Gdańska), czy wschodnich wybrzeży USA.

\section{MAKROFAUNA ANTARKTYCZNA}

Kolekcja ta stanowi zespół organizmów o rozmiarach przekraczajaccych $0,5 \mathrm{~mm}$, które pochodza ze strefy między pływowej i płytkiego litoralu (do $30 \mathrm{~m}$ ). Liczy ponad 5000 okazów, reprezentujących: obunogi, równonogi, wieloszczety, skaposzczety, ślimaki, małże, wirki, wstężnice oraz mszywioły. Najliczniejsze sa ślimaki: Laevilitorina caliginosa (Gould, 1849) i Onoba paucilirata (Melvill \& Standen, 1912) oraz małż Altenaeum charcoti (Lamy, 1906). Wszystkie okazy pochodza z Zatoki Admiralicji (Wyspa Króla Jerzego), obszaru znajdujacego się $\mathrm{w}$ bezpośrednim sasiedztwie Polskiej Stacji Antarktycznej. Bezkregowce te zebrano $z$ trzech stref litoralu w odniesieniu do wysokości pływu, tj. na poziomie niskiego, średniego i wysokiego poziomu pływu, $z$ powierzchni ograniczonej ramka o wymiarach $50 \times 50 \mathrm{~cm}$. Pobrane próbki zakonserwowano $4 \%$ roztworem formaldehydu buforowanego woda morska. Materiał został pobrany podczas lata antarktycznego w 2011 r., a także w cyklu rocznym w sezonie 2016/2017, czyniąc kolekcje cenna ze względu na możliwość uchwycenia zmienności sezonowej $\mathrm{w}$ tym bardzo dynamicznym środowisku.

\section{MAKROFAUNA ZATOKI GDAŃSKIEJ (MORZE BAETYCKIE)}

Zbiór obejmuje drobne bezkręgowce dna morskiego Zatoki Puckiej i przedpola ujśsia Wisły. Zatoka Pucka stanowi unikatowy obszar o stosunkowo wysoko zróżnicowanej faunie, co zwiazane jest $z$ występowaniem w tym rejonie dużej różnorodności siedlisk, w tym dna porośniętego przez podwodna roślinność (SOKOŁOWSKI i współaut. w druku). Obecność i zasięgi występowania podmorskich łak w Zatoce Puckiej ulegały dramatycznym zmianom $\mathrm{w} X X \mathrm{~W}$. Na tym terenie podmorskie zbiorowiska, powszechne do połowy ubiegłego wieku, uległy niemal całkowitej dewastacji w latach 70. (prawdopodobnie w wyniku nadmiernego zrzutu zanieczyszczeń), a od końca XX w. obserwowana jest bardzo szybka naturalna odnowa tych siedlisk (WESEAWSKI i współaut. 2013).

Materiały te były zbierane $\mathrm{w}$ czterech sezonach w latach 2011-2013 przez płetwonurków (do głębokości $5 \mathrm{~m}$ ) oraz podczas rejsu statku s/y Oceania (w zakresie głębokości 16-55 m). Kolekcja ta obejmuje ponad 40 taksonów, przede wszystkim: skorupiaki, 
mięczaki i wieloszczety, które zostały zakonserwowane w 4\% formaldehydzie, a następnie przechowywane w $75 \%$ etanolu. Zmienność przestrzenna i sezonowa oraz występowanie przedstawicieli makrofauny Zatoki Gdańskiej zostały opisane przez WŁODARSKĄ-KowALCZUK i współaut. (2014, 2016).

\section{ZOOPLANKTON MORSKI}

Kolekcja tych organizmów został zgromadzona podczas badań prowadzonych przez IO PAN, jak również przez współpracujące $z$ nim zagraniczne instytuty badawcze. Ze względu na delikatna budowę i mikroskopijne rozmiary ciała, kolekcja morskiego zooplanktonu została przygotowana w oparciu o zbiór próbek tego zespołu, a nie o zbiór pojedynczych osobników. Zbiór ten liczy przypuszczalnie około 36000 okazów. Liczba osobników obecnych w próbce jest zakodowana w bazie danych kolekcji w trzech klasach liczebności: klasa 1 - liczba osobników w próbce od 1 do 9, klasa 10 - liczba osobników od 10 do 99, klasa 100 - liczba osobników powyżej 100. Szacuje się, że kolekcja zooplanktonu morskiego obejmuje ponad 100 gatunków i rodzajów oraz dodatkowo przedstawicieli około 100 taksonów wyższej rangi (organizmy zidentyfikowanych do rangi: typu, gromady, rzędu, czy rodziny). Podstawowy zbiór (próbek) w kolekcji pochodzi $z$ obszaru Mórz Nordyckich (północno-wschodni Atlantyk), a dokładniej $Z$ rejonu Atlantyckiego Pracdu Norweskiego i Prądu Zachodniospitsbergeńskiego oraz $Z$ fiordów archipelagu Svalbard. Drugi ważny obszar, z którego pochodzi zebrany zooplankton to Ocean Arktyczny, w szczególności Basen Nansena i rejon szelfu północnego Morza Barentsa. Główna część materiałów tworzacych opisywaną kolekcje została zebrana w epipelagialu, w powierzchniowej warstwie morza, siegającej teoretycznie do 200 m głębokości lub do dna na obszarach szelfowych, a w fiordach do głębokości około $400 \mathrm{~m}$. Pozostałe próby pozyskano $z$ głębszych warstw morza, $z$ mezopelagialu (do $1000 \mathrm{~m}$ głębokości) lub w batypelagialu do $3000 \mathrm{~m}$ głębokości. Podstawowym narzędziem połowu zooplanktonu były sieci w rodzaju WP-2 z gazą o wymiarze oczek 180 $\mu \mathrm{m}$ i sieć MultiNet Midi również $z$ gaza 180 $\mu \mathrm{m}$. Niektóre $z$ próbek były zebrane sieciami tego samego rodzaju, ale o drobniejszych oczkach gazy filtrującej (sieć WP-2 z gaza $56 \mu \mathrm{m})$ lub sieciami innego rodzaju i $z$ gaza filtrujacca o większych oczkach (sieć WP-3 z gaza $1000 \mu \mathrm{m})$. Ze względu na formę kolekcji (zbiór próbek), podstawowa jej część stanowia okazy charakterystycznych i masowych gatunków dominujacych w próbkach zooplanktonu badanych obszarów morskich.
Szacuje się, że zbiory reprezentują dużą część (prawdopodobnie nie mniej niż 60\%) gatunków i taksonów organizmów zooplanktonowych znanych $z$ literatury przedmiotu dla obszarów, $z$ których pochodza próbki w kolekcji (HoP i współaut. 2006, КоsовоKоVA i współaut. 2011, Hop i współaut. 2019). W tej kolekcji znajda się okazy paratypowe Xantharus siedleckii Schulz \& Kwaśniewski 2004 i Mesaiokeras spitsbergensis Schulz \& Kwaśniewski 2004), gatunków $z$ grupy widłonogów (Copepoda), opisane po raz pierwszy w oparciu o próbki zebrane w fiordach zachodniego Spitsbergenu (ScHULZ i KWAŚNIEWSKI 2004). Większość próbek została zebrana głównie latem w trakcie badań przeprowadzonych w okresie ostatniej dekady (od 2010 r.). Część próbek pozyskano przed 2010 r., jak również w innych sezonach rocznego cyklu funkcjonowania ekosystemów pelagicznych półkuli północnej (wiosna, jesienia, czy zimą). Znaczna część zbiorów stanowia próbki zbierane w ramach badań nad długoterminową zmiennościa zooplanktonu w atlantyckich wodach Prąu Zachodniospitsbergeńskiego (kolekcja rejsów AREX). Ze względu na to, że kolekcja jest obecnie w trakcie tworzenia, dokładne dane opisowe (liczba okazów, liczba taksonów, zakres geograficzny, zakres czasowy) dla niej będa mogły być podane $z$ większą dokładnościa po zrealizowaniu zaplanowanych prac.

\section{PROTISTA (PROTISTY, PIERWOTNIAKI)}

Protista (protisty, pierwotniaki) sa jednym $z$ pięciu królestw wyróżnianych obecnie w hierarchicznych systemach klasyfikacji organizmów, obejmujacym eukariotyczne organizmy jednokomórkowe. Należą tu przedstawiciele organizmów typowo samożywnych (autotroficznych) jak Chlorophyta (zielenice) i Rhodophyta (krasnorosty), auto- mikso- i heterotroficznych jak Chromista (grzybopływki) z Bacillariophyceae (okrzemki), Cryptophyta (kryptofity), Xanthophyceae (różnowiciowce) z Coccolithophyceae (kokolitofory), Ciliophora (orzęski) i Myzozoa z Dinoflagellata (bruzdnice). Dzięki swojej mikroskopijnej postaci osiagaja one olbrzymie liczebności rzędu miliardów osobników w metrze sześciennym wody i obejmuja ogrom środowiska morskiego (około 71\% powierzchni globu). Odpowiadaja za blisko połowę produkcji tlenu na Ziemi, a przez swoje powiazania troficzne wiąża o wiele skuteczniej nadmiar $\mathrm{CO}_{2}$ atmosferycznego niż np. Puszcza Amazońska.

Liczaca 5000 rekordów danych kolekcja planktonowych protistów żyjacych w arktycznym lodzie morskim oparta jest na zbiorach dokonanych głównie w rejonie zachodniego i północnego Svalbardu (WIKTOR i WoJ- 
CIECHOWSKA 2005, SMOŁA i współaut. 2017, HEGSETH i współaut. 2019, DABRowsKA i współaut. 2020). Z racji małych rozmiarów (3-400 $\mu \mathrm{m})$, organizmmy te sa przechowywane $\mathrm{w}$ postaci oryginalnych próbek o objętościach 50-200 ml, które zawieraja wszystkie osobniki $z$ danej próbki i sa zakonserwowane mieszanina płynu Lugola i glutardehydu (odpowiednio 2 i $1 \%$ końcowej koncentracji), bądź mieszaniny formaldehydu i glutardehydu (po 2\% końcowej koncentracji). Część planktonicznych Protista została oznaczona do rangi rodzaju. Dotyczy to szczególnie nieopancerzonych bruzdnic $z$ rodziny Gymnodiniaceae, które $z$ racji zmienności kształtów komórki pod wpływem utrwalania i braku cech rozróżnialnych w mikroskopie świetlnym, sa trudne do poprawnego oznaczenia. Zachowanie tych kolekcji $\mathrm{w}$ formie oryginalnych próbek może pomóc przy ewentualnych uaktualnieniach list gatunkowych badź rewizjach taksonomicznych.

Zbiory morskich Protista obejmuja okazy stanowiące część większej całości próbek zebranych na przestrzeni ostatniego dwudziestolecia. Obejmuja one przedstawicieli Ochrophyta (Bacillariophyceae, Chrysophyceae, Dictyochophyceae) oraz Haptophyta, Dinophyceae, Chlorophyta i Ciliophora. Ponadto $\mathrm{w}$ zachowanym materiale obecna jest szeroka gama nieoznaczonych wiciowców heterotroficznych w przedziale wielkości $<3-20$ $\mu \mathrm{m}$.

\section{Streszczenie}

Instytut Oceanologii Polskiej Akademii Nauk przechowuje 77500 okazów przyrodniczych z obszarów morskich, gromadzonych od 1985 r., czyli od początku istnienia Pracowni Ekosystemów Arktyki, przekształconej później w Zakład Ekologii Morza. Większość zbiorów stanowi zooplankton (około 36000 okazów) zebrany podczas corocznych rejsów badawczych statku s/y Oceania w rejon Mórz Nordyckich. Równie ważne sa niewielkie kolekcje gromadzone przez naukowców zajmujących się poszczególnymi grupami systematycznymi. Zasoby Instytutu obejmuja okazy: mszywiołów (Bryozoa), skorupiaków (Crustacea) $z$ wyodrębniona kolekcja krabów pustelników (Paguroidea), a także stułbiopławów (Hydrozoa), wieloszczetów (Polychaeta), mięczaków (Mollusca), sikwiaków (Sipuncula) oraz szkarlupni (Echinodermata), jak również zbiory pierwotniaków (Protista), meiofauny z wyodrębnionymi kolekcjami ryjkogłowów (Kinorhyncha) i nicieni (Nematoda) oraz makrofauny antarktycznej i Zatoki Gdańskiej.W ramach projektu IMBIO (Integracja i mobilizacja danych o różnorodności biotycznej Eukaryota $\mathrm{w}$ zasobach polskich instytucji naukowych) posiadane kolekcje okazów zostana usystematyzowane i uporządkowane, a dane o zasobach zostana zorganizowane $\mathrm{w}$ postaci cyfrowej, w formie baz metadanych. Idea cyfryzacji danych zawartych w opisach kolekcji naukowych i dzielenia się nimi poprzez organizacje: Krajową Sieć Informacji o Bioróżnorodności (KSIB) i Globalną Usługę Informacji o Bioróżnorodności (GBIF) ułatwi szerszy wgląd i korzystanie $z$ dotychczas niedostępnych zbiorów naukowych.

\section{LITERATURA}

Appeltans W., Ahyong S. T., Anderson G. i współaut., 2012. The magnitude of global marine species diversity. Curr. Biol. 22, 21892202.

BAtAZY P., KuKLIŃSKI P., 2013. Mobile hard substrata - An additional biodiversity source in a high latitude shallow subtidal system. Estuar. Coast. Shelf Sci. 119, 153-161.

BAEAZY P., KUKLIŃSKI P., 2019. Year-to-year variability of epifaunal assemblages on a mobile hard substrate - case study from high latitudes. Mar. Ecol. 39, e12533

BAŁAZY P., KuKLIŃSKI P., WŁODARSKA-KOWALCZUK M., BARNES D. K. A., KEDRA M., LEGEŻYŃSKA J., WESSEAWSKI J. M., 2015. Hermit crabs (Pagurus spp.) at their northernmost range: distribution, abundance and shell use in the European Arctic. Polar Res. 34, 21412.

BOERO F., 2010., The study of species in the era of biodiversity: a tale of stupidity. Diversity 2 , $115-126$.

DĄBROWSKA A. M., WIKTOR J. M. JR., MERChEL M., WIKTOR J.M., 2020. Planktonic protists of the eastern Nordic Seas and the Fram Strait: spatial changes related to hydrography during early summer. Front. Mar. Sci. 7, 557.

D'UDEKEM D'ACOZ C., VADER W., LEGEŻYŃSKA J., 2007. On a new diminutive Rhachotropis species from the North Sea, with a key to European Rhachotropis (Crustacea, Amphipoda, Eusiridae). Bolletino del Museo Civico di Storia Naturalne di Verona, Botan. Zool. 31, 31-49.

GRZELAK K., SøRENSEN M. V., 2018. New species of Echinoderes (Kinorhyncha: Cyclorhagida) from Spitsbergen, with additional information about known Arctic species. Mar. Biol. Res. 14, 113-147.

GRZELAK K., Sørensen M. V., 2019. Diversity and distribution of Arctic Echinoderes species (Kinorhyncha: Cyclorhagida), with the description of one new species and a redescription of E. arlis, Higgins 1966. Mar. Biodivers. 49, 1131-1150.

Hegseth E. N., Assmy P., WiKTOR J. M., WiKTOR J., Kristiansen S., LEU E., TVERBERG V., Gabrielsen T. M., SkOGSETH R., COTTIER F., 2019. Phytoplankton seasonal dynamics in Kongsfjorden, Svalbard and the adjacent shelf. [W:] The Ecosystem of Kongsfjorden, Svalbard. HOP H., WIENCKE C. (red.). Springer International Publishing, 173-227.

Hop H., FALK-PETERSEN S., SvendSEN H., KWASNIEWSKI S., PAVLOV V., PAVLOVA O., i współaut., 2006. Physical and biological characteristics of the pelagic system across Fram Strait to Kongsfjorden. Progr. Oceanograp. 71, 182-231.

Hop H., WOld A., ViHTAKari M., DaAse M., KWASNIEWSKI S., GEUCHOWSKA M., LISCHKA S., BUCHHOLZ F., FALK-PETERSEN S., 2019. Zooplankton in Kongsfjorden (1996-2016) in relation to climate change. [W:] The Ecosystem of Kongsfjorden, Sualbard. HoP H., WIENCKE C. (red.). Springer International Publishing, 229-300.

KEDRA M., SHIELDS M. A., 2011. On the deep-sea Nephasoma species in the Eastern North Atlantic - a taxonomic guide. Mar. Biol. Res. 7, 43-53.

KęDRA M., WŁodARSKA-KowalcZUK M., 2008. Distribution and diversity of sipunculan fauna in high Arctic fjords (west Svalbard). Polar Biol. 31, 1181-1190.

KĘDRA M., GROMISZ S., JASKUŁA R., LEGEŻYŃSKA J., MACIEJEWSKA B., MALEC E., i współaut., 
2010. Soft bottom macrofauna of an All Taxa biodiversity site: Hornsund $\left(77^{\circ} \mathrm{N}\right.$, Svalbard). Pol. Polar Res. 31, 309-326.

KĘDRA M., PABIS K., GROMISZ S., WeSEAWSKI J. M., 2013. Distribution Patterns of Polychaete Fauna in an Arctic Fjord (Hornsund, Spitsbergen). Polar Biology 36, 1463-72

KęDra M., Grebmeier J. M., CoOper L. W., 2018. Sipunculan fauna in the Pacific Arctic region: a significant component of benthic infaunal communities. Polar Biol. 41, 63-74.

KosobokOVA K. N., HOPCROFT R. R., HiRCHE H.J., 2011. Patterns of zooplankton diversity through the depths of the Arctic's central basins. Mar. Biodivers. 41, 29-50.

KOTWICKI L., SzCZUCIŃSKI W., 2006. Meiofaunal assemblages and sediment characteristics of sandy beaches on the west coast of Thailand after the 2004 tsunami event. Phuket Marine Biological Center Research Bulletin.

Kotwicki L., TROCH M. D., URBAN-MALinga B., GHESKIERE T., WeSLAWSKI J. M., 2005. Horizontal and vertical distribution of meiofauna on sandy beaches of the North Sea (The Neth erlands, Belgium, France). Helgoland Mar. Res. 59, 255-264.

Kotwicki L., GrzelaK K., Czub M., Dellwig O., GENTZ T., SZYMCZYCHA B, BÖTTCHER M. E., 2014a. Submarine groundwater discharge to the Baltic coastal zone: Impacts on the meiofaunal community. J. Mar. Syst. 129, 118126.

Kotwicki L., Deidun A., GrzelaK K., Gianni F., 2014b. A preliminary comparative assessment of the meiofaunal communities of Maltese pocket sandy beaches. Estuar. Coast. Shelf Sci. 150, 111-119.

KRZEMINSKA M., SicINSKI J., KUKLIŃSKI P., 2018. Biodiversity and biogeographic affiliation of Bryozoa from King George Island (Antarctica). Syst. Biodivers. 16, 576-586.

KUKLIŃSKI P., 2013. Biodiversity and abundance pattern of rocks encrusting fauna in temperate fjord. Mar. Environ. Res. 87-88, 61-72.

KUKLIŃSKI P., BADER B., 2007. Diversity, structure and interactions of encrusting lithophillic macrofaunal assemblages from Belgica Bank, East Greenland. Polar Biol. 30, 709-717.

KuklińsKi P., Gulliksen B., LøNNE O. J., WeSLAWSKI J. M., 2005. Composition of bryozoan assemblages related to depth in Svalbard fjords and sounds. Polar Biol. 28, 619-630.

LEGEŻYŃSKA J., DEJA K., WŁODARSKA-KOWALCZUK M., 2015. First record of the family Dexaminidae and species Guernea (Prinassus) nordenskioldi in the west Spitsbergen fjords (Svalbard, Greenland Sea). Mar. Biodivers. Rec. 8, 1-5.

OleszczuK B., GRZElaK K., KedRA M., 2021. Community structure and productivity of Arctic benthic fauna across depth gradients during springtime. Deep Sea Res. 170, 103457.

RONOWICZ M., SCHUCHERT P., 2007. Halecium arcticum, (Cnidaria, Hydrozoa), a new hydroid from Spitsbergen. Zootaxa 1549, 55-62.

Ronowicz M., Boissin E., Postaire B., Bourmaud C. A.-F., Gravier-Bonnet N., Schuchert P.,
2017. Modern alongside traditional taxonomy integrative systematics of the genera Gymnangium Hincks, 1874 and Taxella Allman, 1874 (Hydrozoa, Aglaopheniidae). PLoS One 12 , e0174244.

SchUlZ K., KWAŚNIEWSKI S., 2004. New species of benthopelagic calanoid copepods from Kongsfjorden (Spitsbergen, Svalbard Archipelago). Sarsia 89, 143-159.

SMOŁA Z. T., TATAREK A., WiKTOR J. M., WikTOR J. M. JR., KUBISZYN A., WESŁAWSKI J. M., 2017. Primary producers and production in Hornsund and Kongsfjorden - comparison of two fjord systems. Pol. Polar Res. 38, 351373.

SOKOŁOWski A., JANKOWSKA E., BALAZY P., JEDRUCH A., (w druku). Distribution and extent of benthic habitats in Puck Bay (Gulf of Gdańsk, southern Baltic Sea). Oceanologia.

SøRENSEN M. V., GRZELAK K., 2018. New mud dragons from Svalbard: three new species of Cristaphyes and the first Arctic species of Pycnophyes (Kinorhyncha: Allomalorhagida: Pycnophyidae). PeerJ 6, doi $10.7717 /$ peerj.5653.

WEYDMANN A., CARSTENSEN J., GOSZCZKO I., DMOCH K., OLSZEWSKA A., KWAŚNIEWSKI S., 2014. Shift towards the dominance of boreal species in the Arctic: Inter-annual and spatial zooplankton variability in the West Spitsbergen Current. Mar. Ecol. Progr. Series 501, 41-52.

WeYDManN A., WALCZOWSKI W., CARSTENSEN J., KWAŚNIEWSKI S., 2018. Warming of Subarctic waters accelerates development of a key marine zooplankton Calanus finmarchicus. Global Change Biol. 24, 172-183.

WęSŁAWSKI J. M., KRYLA-STRAsZEWSKA L., PIWOWARCZYK J., URBANSKI J., WARZOCHA J., KOTWICKI L., WŁODARSKA-KOWALCZUK M., WIKTOR J., 2013. Habitat modelling limitations - Puck Bay, Baltic Sea - a case study. Oceanologia $55,167-183$.

WIKTOR J., WOJCIECHOWSKA K., 2005. Differences in taxonomic composition of summer phytoplankton in two fjords of West Spitsbergen, Svalbard. Pol. Polar Res. 26, 259-268.

Williams J. D, MCDERMOT J. J., 2004. Hermit crab biocoenoses: a worldwide review of the diversity and natural history of hermit crab associates. J. Exp. Mar. Biol. Ecol. 305, $1-128$.

WŁODARSKA-KOWALCZUK M., 2007. Molluscs in Kongsfjorden (Spitsbergen, Svalbard): a species list and patterns of distribution and diversity. Polar Research 26, 48-63

WŁODARSKA-KOWALCZUK M., JANKOWSKA E., KoTWICKI L., BAEAZY P., 2014. Evidence of season-dependency in vegetation effects on macrofauna in temperate seagrass meadows (Baltic Sea). PLoS One 9, e100788.

WŁoDARSKA-KOWALCZUK M., MAZURKIEWICZ M., JANKOWSKA E., KOTWICKI L., DAMRAT M., ZAJACZKOWSKI M., 2016. Effects of fluvial discharges on meiobenthic and macrobenthic variability in the Vistula River prodelta (Baltic Sea). J. Mar. Syst. 157, 135-146. 
KOSMOS Vol. 70, 2, 183-196, 2021

Marta Ronowicz, Piotr BaŁazy, Maciej CheŁchowski, Kajetan Deja, Katarzyna GrZelak, MoniKa Kędra,

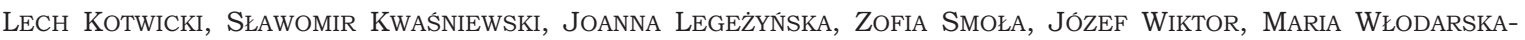
KOWALCZUK, PIOTR KuKLIŃSKI

Department of Marine Ecology, Institute of Oceanology PAS, 55 Powstańców Warszawy Str., 81-712 Sopot, E-mail: martar@iopan.pl

RESOURCES OF INFORMATION ON THE DIVERSITY OF MARINE EUCARYOTA IN THE RESEARCH
COLLECTIONS OF THE INSTITUTE OF OCEANOLOGY OF THE POLISH ACADEMY OF SCIENCES

Summary

The Institute of Oceanology of the Polish Academy of Sciences (IO PAN) stores 77,500 natural history specimens from marine areas, which have been collected since 1985, when the Arctic Ecosystem Laboratory was established, later transformed into the Department of Marine Ecology. The majority of the collection is zooplankton (approximately 36,000 specimens) collected during the annual research cruises with the s/y Oceania ship to the area of the Nordic seas. Some smaller collections organized by individual researchers working with specific systematic groups are equally important. Thus, the Institute's collection resources also include specimens of bryozoans (Bryozoa), crustaceans (Crustacea) with a separate collection of hermit crabs (Paguroidea), as well as hydroids (Hydrozoa), bristle worms (Polychaeta), molluscs (Mollusca), sipunculid worms or peanut worms (Sipuncula), and echinoderms (Echinodermata) as well as protists (Protista), meiofauna with separate collections of kinorhynchs, the spiny-crown worms (Kinorhyncha) and nematodes (Nematoda) as well as Antarctic and Gulf of Gdańsk macrofauna. As part of the IMBIO project (Integration and mobilization of data on the biotic diversity of Eukaryota in the resources of Polish scientific institutions), the specimen collections currently held by the Institute will be systematized and organized, and the data on resources will be digitalized in the form of metadata databases. The idea of digitizing the data contained in the descriptions of scientific collections and sharing them through the Polish Biodiversity Information Network (KSIB) and the Global Biodiversity Information Facility (GBIF) organizations will facilitate a wider insight and use of previously unavailable scientific collections.

Key words: Institute of Oceanology of the Polish Academy of Sciences, marine biodiversity collection, marine invertebrates, natural history collections 